\section{Evaluation of Herbicide Programs in Florida Cabbage Production}

\author{
Jialin Yu and Nathan S. Boyd ${ }^{1}$ \\ Horticultural Sciences Department, Gulf Coast Research and Education \\ Center, University of Florida, Wimauma, FL 33598
}

\section{Peter J. Dittmar \\ Horticultural Sciences Department, 1233 Fifield Hall, University of Florida, Gainesville, FL 32611}

Additional index words. herbicide tolerance, pretransplanting, posttransplanting, sequential application, weed control

\begin{abstract}
In Florida, cabbage (Brassica oleracea $\mathbf{L}$.) is typically grown without a plastic mulch and as a result, weeds are a significant problem in most fields. Experiments were conducted from Nov. 2015 to Apr. 2016 in Balm, Citra, and Parrish, FL, to evaluate weed control and 'Bravo' cabbage tolerance to multiple herbicide programs applied pretransplanting (PRE-T), posttransplanting (POST-T), PRE-T followed by (fb) a sequential application at 3 weeks after transplanting (WATP), and POST-T fb sequential application at 3 WATP. PRE-T herbicide treatments of $277 \mathrm{~g}$ a.i./ha clomazone, $280 \mathrm{~g}$ a.i./ha oxyfluorfen, and $798 \mathrm{~g}$ a.i./ha pendimethalin and POST-T herbicide treatments of $6715 \mathrm{~g}$ a.i./ha dimethyl tetrachloroterephthalate (DCPA) were ineffective, and weed control never exceeded $70 \%$ in Balm and provided $<50 \%$ weed control in Citra and Parrish at 6 and 8 WATP, respectively. POST-T applications of napropamide + S-metolachlor at $2242+1770 \mathrm{~g}$ a.i./ha, DCPA + $\mathrm{S}$-metolachlor at $6715+1170 \mathrm{~g}$ a.i./ha, and S-metolachlor POST-T fb clopyralid at $1170 \mathrm{~g}$ a.i./ha fb $210 \mathrm{~g}$ ae/ha were the most effective herbicide treatments and consistently provided $\mathbf{7 0 \%}$ weed control. In addition, results showed that all of the herbicide treatments evaluated except the PRE application of clomazone at $277 \mathrm{~g}$ a.i./ha are safe for cabbage with no adverse effect on yield.
\end{abstract}

Cabbage (B. oleracea L.) is an important vegetable crop in Florida. In 2010, Florida ranked third nationally in the production of fresh market cabbage accounting for $12.7 \%$ of the U.S. total cabbage production (USDA, 2017a). In 2016, cabbage growers in Florida planted 3439 ha fresh market cabbage and harvested 3197 ha, and the average yield was 36,980 kg.ha ${ }^{-1}$ (USDA, 2017b). Cabbage produced in Florida is exclusively for fresh market with the late fall, winter, and early spring harvests supplying the northern United States (USDA, 2017b).

In Florida, cabbage is typically grown without a plastic mulch and as a result, weeds are a significant problem in most fields. Weed competition may reduce cabbage growth, quality, and yield by competing for nutrients, sunlight, and soil moisture (Al-Khatib et al., 1995; Bhowmik and McGlew, 1986; Hoyt et al., 1996; Webster, 2010). The most common weeds in Florida cabbage production during the peak production period (December through February) are winter annuals such as cutleaf evening primrose (Oenothera laciniata Hill.) and wild radish (Raphanus

\footnotetext{
Received for publication 23 Oct. 2017. Accepted for publication 15 Dec. 2017.

Research funding was provided by Florida Department of Agriculture and Consumer Services. We would like to thank Mike Sweat for technical assistance with this research.

${ }^{1}$ Corresponding author. E-mail: nsboyd@ufl.edu.
}

raphanistrum $\mathrm{L}$ ). However, in late fall or near the end of harvest in early spring, summer annual broadleaf weeds, such as common lambsquarters (Chenopodium album L.), and annual grass species, such as crabgrass (Digitaria spp.) and goosegrass [Eleusine indica (L.) Gaertn.], can be problematic. Yellow (Cyperus esculentus L.) and purple (Cyperus rotundus L.) nutsedges are also a serious issue. Because of its small stature, shallow root system, and thin canopy, cabbage seedlings are poor competitors with weeds. Therefore, controlling weeds early in the season is particularly important to maintain crop vigor and yield (Miller and

As with most minor crops, registered herbicides for use in cabbage are limited. Bensulide, clomazone, DCPA, oxyfluorfen, and trifluralin are registered for preplant incorporated application (Zotarelli et al., 2016). Clethodim, clopyralid, DCPA, napropamide, and sethoxydim are registered for over-thetop applications (Zotarelli et al., 2016). S-metolachlor controls annual broadleaf and grass weeds and suppress nutsedge species (Anonymous, 2014; Bellinder et al., 1989; Sikkema et al., 2007). It is registered with a third-party identified label in Florida, and growers need to sign an agreement with the third-party indemnitors. The field half-life of S-metolachlor is generally $15-25 \mathrm{~d}$ based on direct bioassay measurements in southern states (Shaner, 2014). Now, most cabbage growers in Florida use a single application of S-metolachlor Hopen, 1991; Weaver, 1984). immediately after transplant for weed control. However, a single application typically does not provide season-long weed control.

There are few published studies evaluating weed control and cabbage tolerance of herbicides applied PRE-T or POST-T over the top. The objectives of this research were to evaluate weed control and cabbage tolerance to multiple herbicide programs.

\section{Materials and Methods}

Experiment description. Three field experiments were conducted from Nov. 2015 to Apr. 2016 in Balm (lat. $27.75^{\circ} \mathrm{N}$, long. $82.26^{\circ} \mathrm{W}$ ), Citra (lat. $29.41^{\circ} \mathrm{N}$, long. $82.14^{\circ} \mathrm{W}$ ), and Parrish, FL (lat. $27.58^{\circ} \mathrm{N}$, long. $\left.82.42^{\circ} \mathrm{W}\right)$. Soil at Balm, FL, was Myakka series fine sand (sandy, siliceous, and hyperthermic Aeric Alaquods) with 1.5\% organic matter and a $\mathrm{pH}$ of 6.0. Soil at Citra was Hague sand (loamy, siliceous, semiactive, and hyperthermic Arenic Hapludalfs) with $0.8 \%$ organic matter and a $\mathrm{pH}$ of 6.5 . Soil at Parrish, FL, was Manatee series fine sand (coarse-loamy, siliceous, superactive, and hyperthermic Typic Argiaquolls) with $1.2 \%$ organic matter and a $\mathrm{pH}$ of 6 .

Cabbage 'Bravo' was transplanted on 20 Nov. 2015, 15 Dec. 2015, and 25 Nov. 2015 in Balm, Citra, and Parrish, respectively, when the transplants had four to five leaves. The plots were fertilized and irrigated throughout the season as per industry standards (Zotarelli et al., 2016). Plots consisted of a single raised bed 7.6-m long and $0.71-\mathrm{m}$ wide with two rows of cabbage per bed. Plants were transplanted $38 \mathrm{~cm}$ apart in rows $20 \mathrm{~cm}$ apart. The principal broadleaf weeds were carpetweed (Mollugo verticillata L.), cutleaf evening primrose, FL pusley (Richardia scabra L.), and wild radish in Balm; cudweed (Gamochaeta spp.), cutleaf evening primrose, FL pusley, and red sorrel (Rumex acetosella L.) in Citra; and cutleaf evening primrose, common purslane (Portulaca oleracea L.), and wild radish in Parrish. Goosegrass and purple nutsedge were also present in the experimental area in Citra and Parrish, respectively.

Herbicide treatments were applied with a $\mathrm{CO}_{2}$-pressurized backpack sprayer calibrated to deliver $280 \mathrm{~L} \cdot \mathrm{ha}^{-1}$ of spray volume with a single 8002 EVS nozzle (Teejet Technologies, Wheaton, IL) and a pressure of 0.24 $\mathrm{MPa}$. PRE-T treatments included clomazone at $277 \mathrm{~g}$ a.i./ha, oxyfluorfen at $280 \mathrm{~g}$ a.i./ha, pendimethalin at $798 \mathrm{~g}$ a.i./ha, DCPA + pendimethalin at $6715+798 \mathrm{~g}$ a.i./ha, and oxyfluorfen + pendimethalin at $280+$ $798 \mathrm{~g}$ a.i./ha (Table 1). PRE-T treatments were applied to the bed top at $1 \mathrm{~d}$ before transplanting. POST-T treatments included DCPA at $6715 \mathrm{~g}$ a.i./ha, napropamide at $2242 \mathrm{~g}$ a.i./ha, S-metolachlor at $1170 \mathrm{~g}$ a.i./ha, napropamide + S-metolachlor at $2242+$ $1170 \mathrm{~g}$ a.i./ha, and DCPA + S-metolachlor at $6715+1170 \mathrm{~g}$ a.i./ha. POST-T treatments were applied immediately after transplanting. In addition, the PRE-T fb sequential application at 3 WATP included oxyfluorfen at $280 \mathrm{~g}$ a.i./ha 
Table 1. Product information of herbicides included in programs for Florida cabbage production.

\begin{tabular}{|c|c|c|}
\hline Herbicide & Trade name & Manufacturer \\
\hline Clopyralid & Stinger $^{\circledR} 3 \mathrm{EC}$ & Dow AgroSciences LLC, 9330 Zionsville Road, Indianapolis, IN 46268 \\
\hline DCPA & Dacthal ${ }^{\circledR} 75$ WP & AMVAC, 4100 E. Washington Blvd. Los Angeles, CA 90023 \\
\hline Napropamide & Devrinol $^{\circledast} 50 \mathrm{DF}$ & United Phosphorus, Inc., 630 Freedom Business Center, Suite 402, King of Prussia, PA 19406 \\
\hline Pendimethalin & Prowl ${ }^{\circledR} \mathrm{H}_{2} \mathrm{O}$ & BASF Corporation, 26 Davis Drive, Research Triangle Park, NC 27709 \\
\hline S-metolachlor & Dual Magnum II ${ }^{\circledR}$ & Syngenta Crop Protection, LLC, Greensboro, NC 27419 \\
\hline
\end{tabular}

fb pendimethalin at $798 \mathrm{~g}$ a.i./ha. The POST-T $\mathrm{fb}$ sequential application at 3 WATP included S-metolachlor at $1770 \mathrm{~g}$ a.i./ha fb pendimethalin at $798 \mathrm{~g}$ a.i./ha or clopyralid at $210 \mathrm{~g}$ ae/ha. Weed-free treatments were hand-weeded once per week, whereas nontreated control remained undisturbed throughout the growing season.

Data collection. Weeds were counted in a $61 \times 71-\mathrm{cm}$ quadrat in each plot at 4,5 , and 13 WATP in Balm, and 2 and 8 WATP in Parrish. Grassy weeds and nutsedge were not counted in Balm because they did not occur at this location. Weed control was visually evaluated in Citra at 2, 4, and 6 WATP on a percent scale where 0 equals no control and 100 equals complete desiccation.

Cabbage injury where 0 represents no injury and 100 represents complete desiccation was evaluated at 2, 4, and 8 WATP at all sites. Five cabbage plants in each plot were randomly selected for measuring height and width. Cabbage height was measured at 6 WATP at all sites. Cabbage width was measured at 10 WATP at Balm and Citra. Cabbage heads were harvested on 8 Mar. and 24 Mar. 2016 in Balm and 21 Mar. and 12 Apr. 2016 at Citra. Cabbage was not harvested at the Parrish location because it was accidentally harvested by a farm crew.

Experimental design and data analysis. Treatments were arranged in a randomized complete block design with four replications at all sites. Weed count data were converted to percentage of control. Data were analyzed in SAS (version 9.2; SAS Institute, Inc., Cary, NC) using the PROC GLM. Data were checked for normality and constant variance before analysis. Logarithmic transformation was used when needed to normalize the data. Nontransformed data are presented. Treatment means were compared using the least squares means statement in SAS with the Tukey adjustment at $P=0.05$. Data collected on multiple dates, such as weed control and cabbage yield, were analyzed using the repeated statement.

\section{Results and Discussion}

Weed control. The treatment by date interaction was significant at all sites and as a result, the weed control data are presented separately by date (Table 2). In Balm, POST-T application of S-metolachlor, napropamide + S-metolachlor, and DCPA + $\mathrm{S}$-metolachlor provided $\geq 75 \%$ weed control throughout the growing season (Table 2). Sequential treatments included oxyfluorfen PRE-T fb pendimethalin 3 WATP and S-metolachlor POST-T fb pendimethalin
3 WATP initially provided $<70 \%$ weed control at 4 WATP. However, these treatments were more effective at the end of growing season and provided $90 \%$ and $89 \%$ weed control at 13 WATP, respectively. S-metolachlor POST-T fb clopyralid 3 WATP provided $>75 \%$ weed control throughout the growing season. The PRE-T application of clomazone, oxyfluorfen, and pendimethalin, as well as the POST-T application of DCPA and napropamide were less effective and weed control never exceeded $70 \%$.

In Citra, POST-T application of napropamide, napropamide + S-metolachlor, and DCPA + S-metolachlor, and PRE-T application of oxyfluorfen + pendimethalin, as well as the sequential treatment of S-metolachlor POST-T fb clopyralid provided $>70 \%$ weed control at all ratings (Table 2). POST-T application of S-metolachlor $\mathrm{fb}$ clopyralid 3 WATP was the most effective treatment and provided $\geq 84$ weed control at all ratings. PRE-T application of clomazone at $277 \mathrm{~g} \cdot \mathrm{ha}^{-1}$ and DCPA + pendimethalin at $6715+$ $798 \mathrm{~g} \cdot \mathrm{ha}^{-1}$ initially provided $>70 \%$ weed control at 2 WATP but control declined to $<45 \%$ at 4 and 6 WATP. PRE-T application of pendimethalin and POST-T application of DCPA were less effective and weed control never exceeded $70 \%$.

In Parrish, broadleaves and nutsedges were counted separately at 2 WATP. PRE-T application of oxyfluorfen and DCPA + pendimethalin, and POST-T application of DCPA + S-metolachlor, as well as sequential treatment of S-metolachlor $\mathrm{fb}$ pendimethalin provided $\geq 95 \%$ control of broadleaf weeds. POST-T application of S-metolachlor, napropamide + S-metolachlor, and DCPA + $\mathrm{S}$-metolachlor provided $>80 \%$ control of nutsedges. Sequential treatments included S-metolachlor POST-T fb pendimethalin 3 WATP and S-metolachlor POST-T fb clopyralid 3 WATP provided $90 \%$ and $71 \%$ control of nutsedges, respectively. POST-T application of napropamide + S-metolachlor and DCPA + S-metolachlor provided 78\% and $76 \%$ weed control at 8 WATP (Table 2). Sequential herbicide treatments included S-metolachlor POST-T fb pendimethalin 3 WATP and S-metolachlor POST-T fb clopyralid 3 WATP provided $81 \%$ and $92 \%$ weed control at 8 WATP. The other herbicide treatments were less effective and weed control never exceeded $70 \%$ at 8 WATP.

In summary, the POST-T application of napropamide + S-metolachlor and DCPA + $\mathrm{S}$-metolachlor, and sequential treatment of S-metolachlor fb clopyralid were the most effective herbicide treatments because they consistently provided $>70 \%$ weed control across sites. In addition, PRE-T application of oxyfluorfen, POST-T application of napropamide and S-metolachlor, and PRE-T application of DCPA + pendimethalin, as well as sequential treatments of oxyfluorfen $\mathrm{fb}$ pendimethalin and S-metolachlor $\mathrm{fb}$ pendimethalin were less effective but consistently suppressed weeds across all sites.

A single PRE-T or POST-T application of clomazone, oxyfluorfen, pendimethalin, DCPA, and napropamide did not provide a season-long weed control. A single POST-T application of S-metolachlor was effective in Balm, but this treatment was less effective and provided poor weed control by the end of growing season in Citra and Parrish. This response is not surprising because weeds germinate throughout the growing season, but herbicides break down over time in the soil (Choi et al., 1988; Das et al., 2003; Gillespie et al., 2011; Shaner, 2014). As a result, sequential herbicide applications generally resulted in better weed control compared with a PRE-T-only or POST-T-only application program.

In previous research, Al-Khatib et al (1995) evaluated the control of broadleaf weeds, including common lambsquarters (C. album L.), common chickweed [Stellaria media (L.) vill], hedge mustard [Sisymbrium officinale (L.) Scop.], pineapple weed [Matricaria matricarioides (less.) Porter], shepherd's purse [Capsella bursa-pastoris (L.) Medic.], and redroot pigweed (Amaranthus retroflexus L.), with clopyralid, trifluralin, oxyfluorfen, pendimethalin, pridate, and S-metolachlor in cabbage grown for seed and found that no single herbicide controlled these broadleaf weeds adequately, with the exception of pendimethalin at 1.92 and $3.84 \mathrm{~kg} \cdot \mathrm{ha}^{-1}$, but the combinations of trifluralin + oxyfluorfen, pendimethalin + clopyralid, and oxyfluorfen + pyridate provided effective control. In the present study, improved weed control observed with combinations might be due to the complementary weed control spectrum of each herbicide in the combinations.

Cabbage injury and productivity. Results of variance analysis showed that the site effect was significant $(<0.0001)$ for cabbage injury, height, width, total count, and cumulative yield, and thus, data are presented separately by site. The treatment by time interaction was not significant in any site and as a result, cumulative cabbage counts and yields are presented, whereas cabbage injury, height, and width data are averaged across dates.

In Balm, all herbicide treatments were safe on cabbage and injury never exceeded 


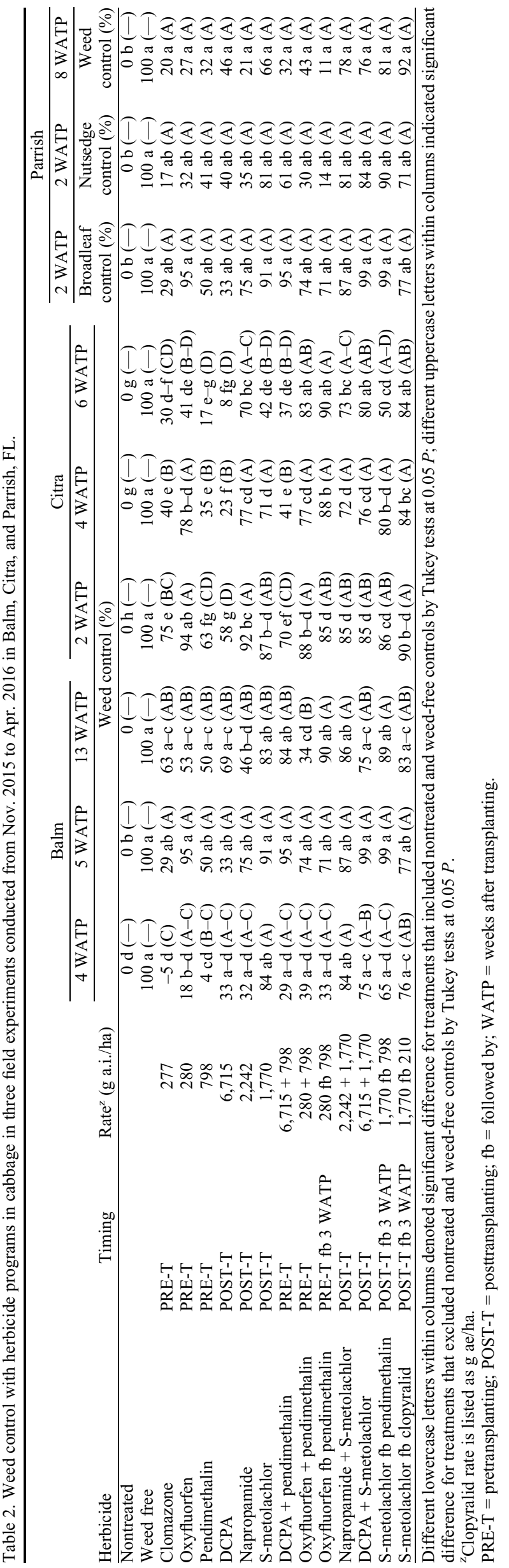

$1 \%$ (Table 3). In Citra, clomazone injured cabbage $64 \%$, whereas all other herbicide treatments injured cabbage $<5 \%$. In Parrish, POST-T application of DCPA, and sequential application of oxyfluorfen PRE $\mathrm{fb}$ pendimethalin 3 WATP, and S-metolachlor POST-T fb clopyralid 3 WAPT injured cabbage the most, but injury never exceeded $11 \%$. All other herbicide treatments injured cabbage $\leq 9 \%$. In addition, individual cabbage head height and diameter were not significantly affected by herbicide treatments (data not shown)

Al-Khatib et al (1995) reported that the PRE-T application of pendimethalin, trifluralin, and oxyfluorfen and POST-T application of clopyralid and metolachlor caused transitory cabbage injury. The authors also noted that sequential treatments included PRE-T fb POST-T treatments of oxyfluorfen $\mathrm{fb}$ clopyralid and pendimethalin fb clopyralid injured cabbage $<7 \%$ by $70 \mathrm{~d}$ after initial treatment. Bhowmik and McGlew (1986) noted that PRE-T application of oxyfluorfen alone at $430 \mathrm{~g} \cdot \mathrm{ha}^{-1}$ or $\mathrm{fb}$ sequential postemergence grass herbicides provided effective weed control without negative effects on cabbage yield and quality. Our results indicated that treatments including S-metolachlor POST-T application is safe on cabbage without harmful effect on cabbage yield. A field research trial conducted in Ontario, Canada, showed that S-metolachlor applied PRE-T and POST-T at 800,1600 , and $2400 \mathrm{~g} \cdot \mathrm{ha}^{-1}$ had an acceptable level of crop safety in cabbage (Sikkema et al., 2007).

There were no significant differences among herbicide treatments and the weedy and weed-free checks for the number of cabbage heads harvested and cumulative yield in Balm. In Balm, the cumulative cabbage head and yield averaged across treatments were 32,117 number/ha and $67,635 \mathrm{~kg} \cdot \mathrm{ha}^{-1}$, respectively (Table 3 ). In Citra, the lowest cumulative cabbage yield was obtained with the clomazone treatment. There was no cabbage harvested from the plots treated with PRE-T application of clomazone. The other herbicide treatments were not significantly different from the weed-free checks. Overall, although several herbicide treatments injured cabbage, the injury was temporary and did not significantly reduce total head count and yield compared with weed-free plots, except the treatment of clomazone.

It is important to note that the PRE-T application of clomazone might be safe for other cabbage varieties. Hopen et al (1993) examined 36 cabbage varieties with differential genetic makeup and found that the cabbage varieties 'Bravo', 'Cheers', and 'Genesis' developed the most severe chlorosis symptoms, whereas the other varieties such as 'Bently', 'Carlton', and 'Cecile' had the least chlorosis following clomazone at 600 and $1100 \mathrm{~g}$ a.i./ha. In the present study, inconsistent cabbage damage across sites by clomazone might be attributed to different environments (Hopen et al., 


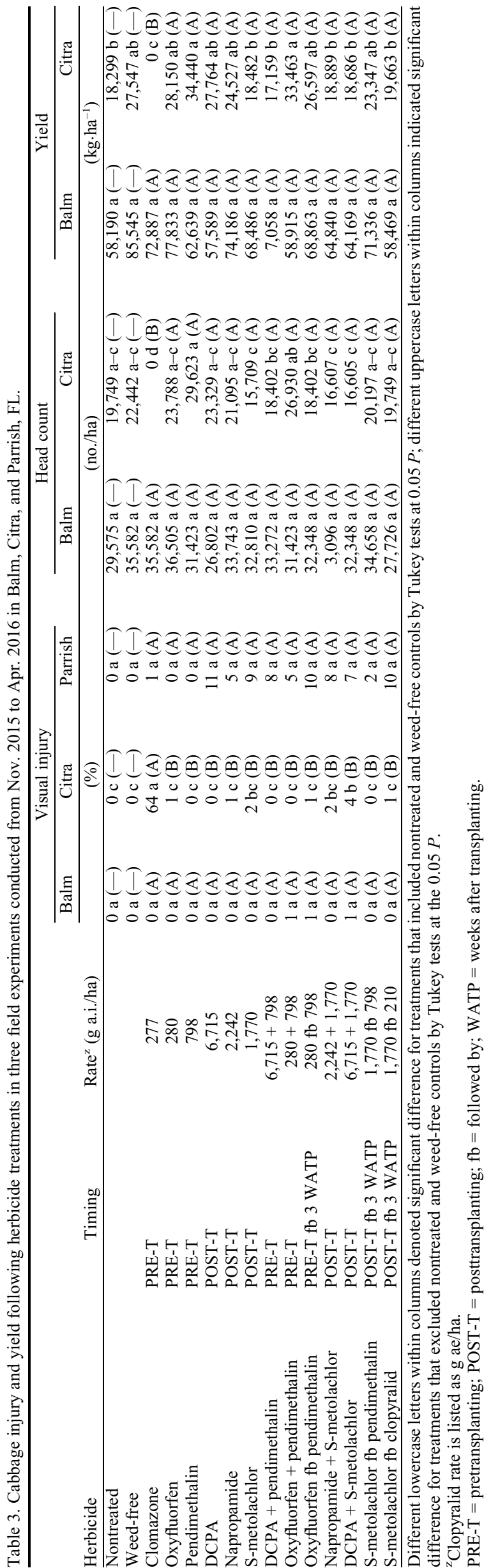

1993; Loux et al., 1989; Shaner, 2014). Hopen et al (1993) reported that cabbage damage by clomazone was more pronounced during a dry soil period. Soil type was also noted to significantly influence the availability and soil persistence of clomazone (Loux et al., 1989; O'barr et al., 2007; Shaner, 2014) and thereby the cabbage tolerance.

In summary, all of the herbicide treatments evaluated except clomazone are safe for use in 'Bravo' cabbage in Florida. The tank-mix combinations of napropamide + S-metolachlor and DCPA + S-metolachlor, and sequential treatment of S-metolachlor fb clopyralid were the most effective herbicide treatments for weed control.

\section{Literature Cited}

Al-Khatib, K., C. Libbey, and S. Kadir. 1995 Broadleaf weed control and cabbage seed yield following herbicide application. HortScience 30:1211-1214.

Anonymous, 2014. Dual II magnum. Syngenta Crop Protection, LLC, Greensboro, NC.

Bellinder, R., D. Wilcox-Lee, A. Senesac, and D. Warholic. 1989. Response of earlymaturing cabbage (Brassica oleracea var. capitata) to metolachlor. Weed Technol. 3:463466.

Bhowmik, P.C. and E.N. McGlew. 1986. Effects of oxyfluorfen as a pretransplant treatment on weed control and cabbage yield. J. Amer. Soc. Hort. Sci. 111:686-689.

Choi, J., T. Fermanian, D.J. Wehner, and L. Spomer. 1988. Effect of temperature, moisture, and soil texture on DCPA degradation. Agron. J. $80: 108-113$

Das, A.C., A. Debnath, and D. Mukherjee. 2003. Effect of the herbicides oxadiazon and oxyfluorfen on phosphates solubilizing microorganisms and their persistence in rice fields. Chemosphere 53:217-221.

Gillespie, W.E., G.F. Czapar, and A.G. Hager 2011. Pesticide fate in the environment: a guide for field inspectors. Contract Rpt. $7: 5-12$.

Hopen, H.J., R.L. Hughes, and B.A. Michaelis 1993. Selectivity among cabbage (Brassica oleracea L.) cultivars by clomazone. Weed Technol. 7:471-477.

Hoyt, G.D., A.R. Bonanno, and G.C. Parker. 1996 Influence of herbicides and tillage on weed control, yield, and quality of cabbage (Brassica oleracea L. var. capitata). Weed Technol. 10:50-54

Loux, M.M., R.A. Liebl, and F.W. Slife. 1989 Availability and persistence of imazaquin, imazethapyr, and clomazone in soil. Weed Sci. 37:259-267.

Miller, A.B. and H.J. Hopen. 1991. Critical weedcontrol period in seeded cabbage (Brassica oleracea var capitata). Weed Technol. 5:852857.

O'barr, J.H., G.N. McCauley, R.W. Bovey, S.A. Senseman, and J.M. Chandler. 2007. Rice response to clomazone as influenced by application rate, soil type, and planting date. Weed Technol. 21:199-205.

Shaner, D.L. 2014. Herbicide handbook. 10th ed., p. $110,134,320$, 406. In: K.S. Lawrence (ed.). Weed Sci. Soc. America, Lawrence, KS.

Sikkema, P.H., N. Soltani, W. Deen, and D.E. Robinson. 2007. Effect of S-metolachlor 
application timing on cabbage tolerance. Crop Prot. 26:1755-1758.

USDA. 2017a. Cabbage statistics, United States Department of Agriculture, Economics, Statistics and Market Information System. 12 June 2017. $<$ http://usda.mannlib.cornell.edu/MannUsda/ viewDocumentInfo.do?documentID=1397>.

USDA. 2017b. Cabbage statistics, United States De-partment of Agriculture, National Agricultural
Statistics Service. 20 May 2017. <https://quickstats. nass.usda.gov>.

Weaver, S.E. 1984. Critical period of weed competition in three vegetable crops in relation to management practices. Weed Res. 24:317325.

Webster, T. 2010. Weed survey-southern states: cucurbits, fruiting vegetables, cole crops and greens, other vegetables, peaches, apples, fruits and nuts, citrus crops. Proc. South Weed Sci. Soc. 63:250.

Zotarelli, L., P.J. Dittmar, M.O. Ozores-Hampton, N.S. Dufault, P. Stansley, H.A. Smith, S.E. Webb, Q. Wang, and C. Miller. 2016. Cole crop production. p. 33-51. In: G. Vallad, J. Freeman, and P. Dittmar (eds.). Vegetable production handbook for Florida 2016-2017. Univ. Florida's Inst. Food Agr. Sci., Gainesville, FL. 